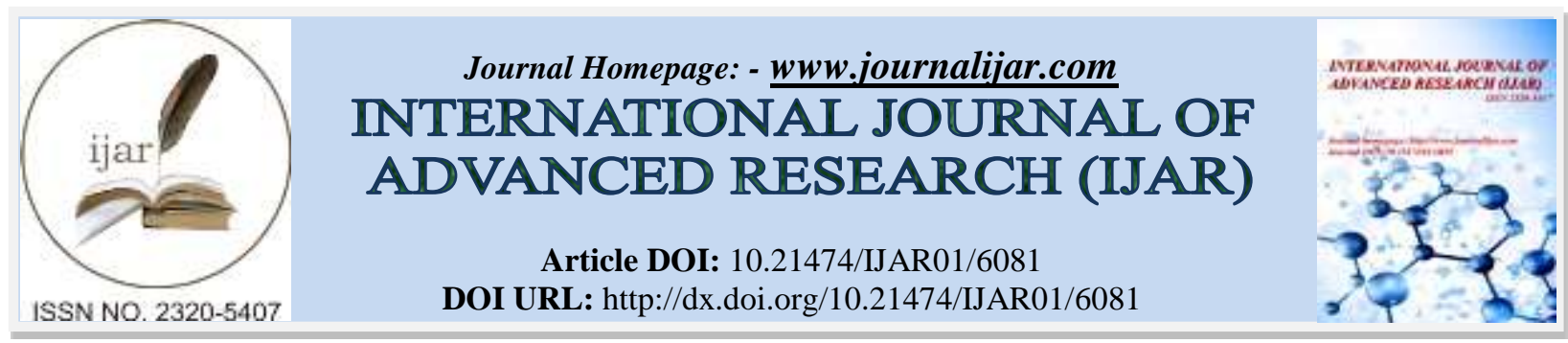

RESEARCH ARTICLE

\title{
COMPARISON OF STUDENT LEARNING ACHIEVEMENT BETWEEN CLASSES TAUGHT BY USING LECTURE METHOD AND DISCUSSION METHOD ON BIOLOGICAL RESPIRATORY SYSTEM MATERIAL IN GRADE VIII JUNIOR HIGH SCHOOL I LIQUICA DISTRICT - EAST TIMOR
}

Joãozito Bareto.

\section{Manuscript Info}

Manuscript History

Received: 17 October 2017

Final Accepted: 19 November 2017

Published: December 2017

Key words:-

Learning achievement biology learning method.

\section{Abstract}

Joãozito Bareto. 2017 "The Comparative Study of Student Learning Achievement Between Classes Taught By Using Discussion Method On Biological Respiratory System Material In Grade VIII Junior High School of Liquica District of East Timor"Supervisor I Prof. Drs. Josua Bire, M.A. M.Ed., PhD Advisor II. Gerardus Uda, M.Pd Examiner I Prof. Dr. Mintje R Oedjoen, M.Pd Examiner II Dr. Andy Nabu Sogen, M.Pd

The aimsof study to determine the differences students' achievement and to know the response of grade VIII students of SMP Negeri I Liquica Timor Leste on biology subject of human respiratory system by using learning method. Discussion Method in using pre-test and posttest design as class (Experiment) the discussion method as class (Control). The Aspects studied include student's achievement as an indicator of improving the learning outcomes. The steps used in this study are the initial of pre-test before teaching and learning process the human respiratory system in experimental class and control class to know the students' achievement before being treated, then human respiratory system which is taught by using lecture and discussion method after completion the teaching is done post-test at the end of learning. The results of this study indicate that there is a difference between student's achievement in biology subject sub subject of human respiratory system of learning that is the lecture method as the experimental class and the discussion method as control class has mastery. The lecture method is $74 \%$ and the discussion method is $93 \%$.

Copy Right, IJAR, 2017,. All rights reserved.

\section{Introduction:-}

The progress of a nation is highly dependent on human resources. Education as a role of formation of human identity which is often known as human resources (HR), a State whose minimal education will affect the growth and Development State. Therefore education is a major factor in formation of the quality human beings to face the competition in various fields both in field of education and technology in progress of each State so that there is need for change and development in the world of education to advance the interests of a State. Education is the most powerful weapon you can use to changethe world (Nelson Mandela). 
According to the National Constitution of Timor-Leste's RDTL, article 59 speaks of East Timor's education in which the State shall recognize the right of every citizen to education and the State shall promote the establishment of a universal system and compulsory education for East Timor. Whereas according to Law no. 20 of 2003 on the Indonesian National Education system, Education is a conscious and planned effort to realize the learning atmosphere and learning process so therefore the learners are actively. Developing his potential to have spiritual power, self-control, personality, intelligence, noble character, and skills needed himself, society, nation and state.

For human education is an inevitable necessity. Thus human education will be directed to be a human bersusial and improve the standard of living. The nation will advance if it has the next generation who mastered science and technology. One of the efforts that can be done is to improve the quality of education through improving student learning outcomes by the use of good learning method, method is a way used to achieve defined learning objectives, in the sense of way pursued by a teacher in delivering teaching materials. Due to rapid development of science and technology, it requires the State of East Timor to improve the quality and quality of education in order to be able to compete with the countries of the world.

Quality of education related to the learning process, because in the process of learning to teach the interaction between teachers and students and the process of teaching and learning will cause a positive impact. In this case teachers and students play an important role quality of education. Measurement of the achievement quality of education poured in student achievement. Furthermore, student achievement is manifested in academic achievement measured through learning outcomes.

Student learning outcomes are very important in education system because it is an indicator of achievement of the planned target. For teachers the results of learning is not only an indicator of success in conveying material to students but the use of methods in teaching and learning process to determine the students who have reached the minimum mastery and entitled to continue the next level. For students learning outcomes become benchmarks mastery of material submitted by teachers. For schools, learning outcomes will increase the credibility and reputation of schools both in community and world of education in general, while for department and educational institutions the results of student learning into the evaluation of the implementation of curriculum in schools.

Learning methods are different ways of achieving different learning outcomes under the different conditions based on defined learning competencies, learning methods are important part of teaching and learning process that students are expected to have. According Sanjaya (2009: 77) that teachers as one source of learning must be provide a creative learning environment for learning activities in classroom students. Active learning of learners will be easier to find and understand difficult concepts when they can discuss the matter with their friends. One of the active learning method is the lecture method and the method of discussion in this study the authors use both methods on subject of Biology subject of the respiratory system in humans this is reinforced by Hamdani (2010: 156 and 159) explaining the various teaching methods such as lecture method and discussion according to lecture method is in the form of explanation of concepts, principles and facts closed with question and answer between teachers and students while the method of discussion is interaction between students and teachers analyze solve the problem of digging or debating a particular topic.

Student achievement can be determined by measuring level of Effectiveness is the principle choosing the things that must be considered in using learning strategies. The quality of learning in classroom is a major factor in achievement of learning objectives. It is also a formation of student mindset that will affect the actions and attitudes of children in the environment outside school. The learning process can be achieved through improving the quality of teachers and also the knowledge of teachers on other learning support factors such as principals, librarians, magazines, videos and other learning media as well as other learning resources. Learning achievement is related to achieve in obtaining capabilities in accordance with the specific objectives planned. Thus the main task of teachers in this activity is to design an instrument that can collect data about the success of students to achieve learning objectives. Based on these data the teacher can develop and improve the learning program while the task as a designer in determining learning achievement in addition to determining the instrument and criteria.

So therefore encourages researchers to raise the problem of this study is detail student achievement on every year is always unbalanced will be influenced by the use of learning methods or influenced by other factors, such as school facilities, teacher factor, student factor itself and many students in one class as well as family economic factors. All these factors are not studied by all researchers only on teaching methods, on biological materials. 
The background, the authors raise this study with the title Comparative study of student learning achievement between classes by using speech methods and discussion methods on the material of human respiratory system biology subjects in grade VIII students SMP Negeri I Liquisa Timor Leste.

\section{Problem statement:-}

Based on the title and background of research there are some problems for researchers are:

1. Is there any influence with the use of teaching methods Lectures and methods on learning achievement?

2. What is the student's response to use the discussion methods on biological materials on student achievement?

3. Is there any significant in learning achievement about being taught by discussion method?

\section{Objectives and Benefits of Research:-}

\section{Research Object:-}

The aim of this research is to know whether there is influence of independent variable to dependent variable, in detail as for the purpose of this research are:

1. To know whether there is influence of learning with Lecture method to student achievement.

2. To know whether student responses to learn by discussion method and lecture on student achievement.

3. To find out whether there is a singular difference for student achievement in using discussion methods.

\section{Benefits of research:-}

Throughthis research is expected to provide information inputs and images based on conceptual study and factual field findings on Student Prediction on subject of human respiratory system biology subjects using discussion methods.

\section{Theoretically:-}

Can provide inspiration in applying results of research and experience significantly, especially in improving student achievement

For teaching methods, this research will provide theoretical development discourse especially related teaching method.

\section{Practically:-}

1. This research provides many useful information in the development of student achievement in the future

2. As a reference in doing research related to the use of good teaching methods.

\section{Research methods:-}

Research design:-

Themethod used in this research isquasi experiment method (Quasi Experiment). Experiments are one type of experimental research. This experimental design form is a development of true experimental design, which is difficult to implement.

The design of this research used pre-test-post-test control group design, with initial test design and final test with comparison group.

\begin{tabular}{|cccc|}
\hline $\mathrm{E}$ & $\mathrm{O} 1$ & $\mathrm{Xe}$ & $\mathrm{O} 2$ \\
$\mathrm{~K}$ & $\mathrm{O} 3$ & $\mathrm{Xk}$ & $\mathrm{O} 4$ \\
& & & \\
\hline
\end{tabular}

\section{Information:-}

E : Experimental group

$\mathrm{K}$ : Control group

O1 : Pre-test in experimental group

O2 : Post-test in experimental group

O3 : Pretest in control group 
O4 : Pre-test in control group

$\mathrm{Xe} \quad$ : Treatment in experimental group in form of learning using Lecture teaching method

$\mathrm{Xk} \quad$ : Treatment in control group in form of learning by using discussion method

The research design above, using two groups of research subjects, are: experimental group and control group. The experimental group was the treated group (using the teacher method) while the control group was the untreated group (using the discussion method).

Operational definition of research variables:-

This research involves variable, two independent variables and one dependent variable. The independent variable is used of learning method of teacher and discussion (X1) and biology subject (X2) while the dependent variable is student's learning achievement $(\mathrm{Y})$.

\section{Place and time of research:-}

The research location will be conducted at SMP Negeri I Liquisa Timor Leste, with 1 month research period starting from May to June 2017.

Research Instrument:-

Development of research instruments:-

Instruments used to collect data in the form of learning implementation plans, observation sheets and questions to measure students' cognitive learning outcomes. Student learning achievement cognitive and student learning activities. The following steps

\section{Early stage:-}

1. Determine the purpose of conducting the test.

2. Refueling the material to be tested

3. Determine the type of problem (this study uses multiple choice questions)

4. Determine the time to do the problem

5. Write down the items

6. Test instruments

\section{Stage analysis:-}

Analyze test instrument test results in terms of validity, reliability, readability and difficulty

Selecting items that have been tested based on data analysis performed

\section{Test of the validity of Question Item:-}

A valid instrument means the measuring instrument used to get the data (measure) is valid. Valid means the instrument can be used to measure what should be measured. (Sugiyona, 2008: 121).

Table 1:- instrument test result

\begin{tabular}{|c|r|r|r|r|}
\hline Class & $\mathbf{N}$ & Item about & lowest score & Highest score \\
\hline Pre-test teacher method (experimental class) & 21 & 10 & 50 & 70 \\
\hline Post-test teacher method (experimental class) & 21 & 10 & 50 & 80 \\
\hline Pre-test discussion method (control class) & 21 & 10 & 50 & 100 \\
\hline Post-test discussion method (control class) & 21 & 10 & 60 & 100 \\
\hline
\end{tabular}

Test of the validity of Question Item:-

Validity is a measure used to determine the level of validity or error of an instrument. If a valid or wrong instrument has a high valid, while the instrument is said to be valid, it means having a low validity. Each item becomes a research instrument. After each item the question is answered by the student is tabulated and tested its validity. Validates those are entered whether every grain problem or all test questions, thus each problem corrected between each question from no 1-10, to test the results that really fail then the results of the author using the computer program SPSS 22.0.

Test the validity of problem for pre-test teacher method (experimental class).

In table valid pre-test method of experimental class teacher method, it can be seen the value of correlation 
coefficient is; 0.876 each item is bigger than the value at a significant level of $5 \%$ and $\mathrm{N}=21$ is 0.433 , so the whole items in the experimental class teacher method is valid.

\begin{tabular}{|c|c|c|c|}
\hline No Item & Count & Table & Description \\
\hline 1. & 0,406 & 0,433 & Valid \\
\hline 2. & 0,407 & 0,433 & Valid \\
\hline 3. & 0,713 & 0,433 & Valid \\
\hline 4. & 0,703 & 0,433 & Valid \\
\hline 5. & 0,843 & 0,433 & Valid \\
\hline 6. & 0,787 & 0,433 & Valid \\
\hline 7. & 0,787 & 0,433 & Valid \\
\hline 8. & 0,908 & 0,433 & Valid \\
\hline 9. & 0,944 & 0,433 & Valid \\
\hline 10. & 0,909 & 0,433 & Valid \\
\hline 11. & 0,876 & $\mathbf{0 , 4 3 3}$ & Valid \\
\hline 12. & 0,886 & 0,433 & Valid \\
\hline 13. & 0,550 & 0,433 & Valid \\
\hline 14. & 0,406 & 0,433 & Valid \\
\hline 15. & 0,872 & 0,433 & Valid \\
\hline 16. & 0,828 & 0,433 & Valid \\
\hline 17. & 0,887 & 0,433 & Valid \\
\hline 18. & 0,878 & 0,433 & Valid \\
\hline 19. & 0876 & 0,433 & Valid \\
\hline 20. & 0678 & 0,433 & Valid \\
\hline 21. & 0,878 & 0,433 & Valid \\
\hline
\end{tabular}

The validity test of questions for pre-test teacher method (experimental class).

In valid table pre-test method of experimental class teacher, it can be seen the value of correlation coefficient is: 0.992 each item is bigger than the value at $5 \%$ significant level and $\mathrm{N}=21$ is 0.433 , the item in experimental class teacher method is valid

\begin{tabular}{|r|r|r|r|}
\hline No. Item & Count & Table & Observation \\
\hline 1. & 0,406 & 0,433 & Valid \\
\hline 2. & 0,407 & 0,433 & Valid \\
\hline 3. & 0,713 & 0,433 & Valid \\
\hline 4. & 0,703 & 0,433 & Valid \\
\hline 5. & 0,843 & 0,433 & Valid \\
\hline 6. & 0,787 & 0,433 & Valid \\
\hline 7. & 0,787 & 0,433 & Valid \\
\hline 8. & 0,908 & 0,433 & Valid \\
\hline 9. & 0,944 & 0,433 & Valid \\
\hline 10. & 0,909 & 0,433 & Valid \\
\hline $\mathbf{1 1 .}$ & $\mathbf{0 , 8 7 6}$ & $\mathbf{0 , 4 3 3}$ & Valid \\
\hline 12. & 0,886 & 0,433 & Valid \\
\hline 13. & 0,550 & 0,433 & Valid \\
\hline 14. & 0,406 & 0,433 & Valid \\
\hline 15. & 0,872 & 0,433 & Valid \\
\hline 16. & 0,828 & 0,433 & Valid \\
\hline 17. & 0,887 & 0,433 & Valid \\
\hline 18. & 0,878 & 0,433 & Valid \\
\hline 19. & 0876 & 0,433 & Valid \\
\hline 20. & 0678 & 0,433 & Valid \\
\hline 21. & 0,878 & 0,433 & Valid \\
\hline
\end{tabular}


Test the validity of question for pre-test discussion method (control class).

In table valid pre-test method of control class discussion, it can be seen the value of correlation coefficient is: 0.998 each item is bigger than the value at $5 \%$ significant level and $\mathrm{N}=21$ is 0.433 , the item in experimental class lecture method is valid.

\begin{tabular}{|r|r|r|r|}
\hline No Item & Count & Table & Observation \\
\hline 1. & 0,992 & 0,433 & Valid \\
\hline 2. & 0,992 & 0,433 & Valid \\
\hline 3. & 0,992 & 0,433 & Valid \\
\hline 4. & 0,987 & 0,433 & Valid \\
\hline 5. & 0,992 & 0,433 & Valid \\
\hline 6. & 0,981 & 0,433 & Valid \\
\hline 7. & 0,992 & 0,433 & Valid \\
\hline 8. & 0,987 & 0,433 & Valid \\
\hline 9. & 0,987 & 0,433 & Valid \\
\hline 10. & 0,991 & 0,433 & Valid \\
\hline 11. & $\mathbf{0 , 9 9 8}$ & $\mathbf{0 , 4 3 3}$ & Valid \\
\hline 12. & 0,999 & 0,433 & Valid \\
\hline 13. & 0,989 & 0,433 & Valid \\
\hline 14. & 0,987 & 0,433 & Valid \\
\hline 15. & 0,988 & 0,433 & Valid \\
\hline 16. & 0,998 & 0,433 & Valid \\
\hline 17. & 0,997 & 0,433 & Valid \\
\hline 18. & 0,966 & 0,433 & Valid \\
\hline 19. & 0,999 & 0,433 & Valid \\
\hline 20. & 0,999 & 0,433 & Valid \\
\hline 21. & & 0,433 & Valid \\
\hline
\end{tabular}

The validity of questions for pre-test teacher method (experimental class).

In table of valid pre-test method of experimental class teacher, it can be seen the value of correlation coefficient is: 0.496 each item is bigger than the value at $5 \%$ significant level and $\mathrm{N}=21$ is 0.433 , the value of the correlation coefficient is smaller than 0.005 , so the whole item in the control class of the discussion method on the post-test is invalid.

\begin{tabular}{|l|r|r|r|}
\hline No Item & Count & Table & Observation \\
\hline 1. & 0,000 & 0,433 & Valid \\
\hline 2. & 0.000 & 0,433 & Valid \\
\hline 3. & 0,000 & 0,433 & Valid \\
\hline 4. & 0,181 & 0,433 & Valid \\
\hline 5. & 0,411 & 0,433 & Valid \\
\hline 6. & 0,271 & 0,433 & Valid \\
\hline 7. & 0,001 & 0,433 & Valid \\
\hline 8. & 0,181 & 0,433 & Valid \\
\hline 9. & 0,213 & 0,433 & Valid \\
\hline 10. & 0,200 & 0,433 & Valid \\
\hline 11. & $\mathbf{0 , 4 9 6}$ & $\mathbf{0 , 4 3 3}$ & Valid \\
\hline 12. & 0,000 & 0,433 & Valid \\
\hline 13. & 0,000 & 0,433 & Valid \\
\hline 14. & 0,000 & 0,433 & Valid \\
\hline 15. & 0,447 & 0,433 & Valid \\
\hline 16. & 0,362 & 0,433 & Valid \\
\hline 17. & 0,431 & 0,433 & Valid \\
\hline 18. & 0,496 & 0,433 & Valid \\
\hline 19. & 0,129 & 0,433 & Valid \\
\hline 20. & 0,496 & 0,433 & Valid \\
\hline 21. & 0,447 & 0,433 & \\
\hline
\end{tabular}




\section{Test Reliability test:-}

Reliability refers to notion that an instrument can measure something that is measured consistently from time to time. So the keywords for qualifying terms of a measuring instrument are consistency, stability or unchanged. The reliability using the kuder-Richardson 20 formula as follows:

count $=\mathrm{n} /(\mathrm{n}-1)\left(1 \Sigma \mathrm{pq} /\left(\mathrm{s}^{\wedge} 2\right)(3.2)\right.$

information:

$\mathrm{r} \quad$ : Overall reliability coefficient

n : Many items

$\mathrm{p} \quad$ : The proportion of subjects who responded wrongly $(q=1-p)$

$\Sigma p q \quad:$ The number of multiplications between $\mathrm{p}$ and $\mathrm{q}$

$\mathrm{S}:$ Standard deviation of the test (standard deviation is the root variance)

(Suharsimi 2007: 101)

Price count to obtain compared with table with $5 \%$ significance level if the count $=0,7363$ and table $=0,230$, then test question including reliable criteria.

Test The difficulty level question

The formula used to determine the problem level is:

$\mathrm{P}=\mathrm{B} / \mathrm{JS}(3.3)$

Information :

$\mathrm{P}=$ difficulty index

$\mathrm{B}=$ many students who answer the question is true

$\mathrm{JS}=$ total of all test participant students The classification of the difficulty index is as

follows: $0.00<\mathrm{P}<0.30$ is a difficult problem $0.30<\mathrm{P}<0.70$ is a moderate problem

$0.70<\mathrm{P}<1.00$ is a relatively easy problem (Suharsimi 2007: 209) Based on the test results obtained criteria questions as follows:

\begin{tabular}{|l|l|l|}
\hline medium, & $4,5,9$ & 3 \\
\hline Difficult & $6,7,8,10,3$ & 5 \\
\hline Amount & 1,2 & 3 \\
\hline Amount & 10 \\
\hline
\end{tabular}

d. Power test differentiator Differentiating power is the ability of problem to distinguish between high-

ability students and low-ability students.

The magnitude of the distinguishing power (D) can be written by the following formula:

DP = JBA-JBB (3.4) JSA

Information:

DP $=$ Power Differentiator

JBA $=$ Large number of items from the top group

$\mathrm{JBB}=$ The correct number in the item from the lower group

JSA $=$ The number of students in the upper group Classification of distinguishing power:

$0.00<\mathrm{DP}<0.20$ : Poor

$0.20<\mathrm{DP}<0.40$ : Enough

$0.40<\mathrm{DP}<0.70$ : Good

$0.70<$ DP < 1.00: very good (Suharsimi 2007: 213)

The classification of the differentiating power of the test results is:

\begin{tabular}{|l|l|l|}
\hline Very well & $1,2,3$ & 3 \\
\hline Good & 6,7 & 2 \\
\hline Enough & $4,5,9$ & 3 \\
\hline Ugly & 8,10 & 2 \\
\hline Amount & 10 \\
\hline
\end{tabular}

Test Perquisite Analysis / Assumption test Normality test Normality test in this research is used to know whether data of research result is normal or not distributed. in test the normality using chi-

square is formulated as follows: $\mathrm{X} 2$ count $=\Sigma_{-}(\mathrm{i}-1)^{\wedge} \mathrm{k}\left(\mathrm{f} \_0 / \mathrm{f} \_\mathrm{h}\right)$

Information: $\mathrm{X} 2=$ chi squared fo $=$ observed frequency fh $=$ expected frequency if $\mathrm{X} 2$ count 
$<\mathrm{x} 2$ table then the data is normally distributed (sugiyono 2007: 104)

Homogeneity Test At the beginning of this study, researchers also used homogeneity test to determine whether the sample to be examined is homogeneous or not. The statistical hypothesis:

Ho: $=$ There is no difference between variance 1 and variance 2 (data is homogeneous)

$\mathrm{Ha}=$ There is a breakdown between variance 1 and 2 (non homogeneous data)

Homogeneity test was performed using the following formula:

$\mathrm{F}$ arithmetic $=($ largest varins $) /($ smallest varins $)(3.6)($ Sudjana, 2005: 250) If F arithmetic $<$ Ftabel then Ho accepted means data is homogeneous, if $\mathrm{F}$ arithmetic $>$ Ftable Ho rejected

which means data is not homogeny. Normal (sugiyono 2007: 104) Test -t for two groups.

So the data in this research is done by comparing the data of two groups of samples, between the experimental group and the control group then tested the comparative hypothesis with t-

test with the hypothesis is in chapter IV. Completed Learning Achievement

In this study as an indicator of learning completeness is where if all students can complete or achieve the goal of learning at least $60 \%$ and at least $80 \%$ of students who are inthe

class. The formula used in this study results thoroughly. (The total number of completed students) / (total number of students)

\section{Research result:-}

In this research, data analysis is done descriptive and inferential statistic.

With the results of his research as follows: Studying in school is an obligation for every student. Time spent in studying classified as long from 1.00 to 5.45 hours, and the time is that given at the State Junior High School I Liquisa 30 minute which is divided in two breaks 15 minute for the first break from 3:00 to 3:15 hours while the second rest hour 4.00 to 4.15 , the time given for very long learning and very little rest time makes the students very saturated. Besides, the level of material difficulty that must be absorbed by the students will make the time to study longer because they have to learn more. In this research has been written achievement of student learning outcomes on the material of the respiratory system using teaching methods Lecture by using experimental class and Discussion method using control class by using descriptive statistic until hypothesis test has been described in previous section in this chapter.

The following is an explanation of the research results obtained.

1. Comparison of student achievement between classes taught using Lecture method and Discussion method. Based on data from the minimum and maximized values of research on the use of lecture and discussion methods are: the pretest test value at the lowest lecture method 50 and 70 high after being treated in the test again with the post-test the lowest value remains 50 while the highest score increased to 80 , whereas on the method of discussion the highest pre-test value of 50 and the highest 100 after the post-test treatment the lowest value increased to 60 and the highest value remained 100. The data suggests that the method of interpretation is lower than the discussion method.

2. Class VIII student response of State Junior High School I Liquisa Timor Leste to the use of Lecture method and Discussion method on biology subject matter of human respiratory system. Based on the results of the students' responses on the use of lecture method by $74 \%$ and the discussion method $93 \%$ of this data indicates that the chooses of the lecture method is smaller than the discussion method.

3. Relationship use of lecture method and discussion of biology subject to student's learning achievement, there is difference method.

The relationship between the use of methods and the biology subjects to the students' learning achievement is closely related to the biology subject of the selection of unsuitable methods will affect student achievement, so in this study the lecture method is smaller than the discussion method.

\section{Conclusion:-}

Based on the results of research and discussion of this study can be summarized as follows:

1. Comparison of student achievement using learning method that is: lecture method and method of discussion, on pre-test for 50-70 and 50-70 lecture method while 50-100 pre-test method and post-test 60-100 . The lecture method is less than the method of discussion. 
2. The calculation of the category states that $64.82 \%$ of students stated positive responses to learning by using the method of discussion (control class) while in the method Lecture (experimental class) students stated positive response of $94 \%$ So in this study the use of discussion methods ( control class) is greater than the lecture method (experimental class) is only $74 \%$.

3. Relationship use of lecture method and discussion of biology subject to student's learning achievement, there is difference method.

The relationship between the use of methods and the biology subjects to the students' learning achievement is closely related to the biology subject of the selection of unsuitable methods will affect student achievement, so in this study the lecture method is smaller than the discussion method.

\section{Suggestions:-}

As for some suggestions related to this research then, some parties who need to receive suggestions from research are:

1. The teacher Teachers can use optimal learning methods in the delivery of biological materials.

2. The student Students can use the learning method independently with the help of teachers and learning support facilities

3. The school side Schools can optimize learning facilities in the teaching and learning process on biological materials with the use of suitable learning methods for biological materials.

4. For other research

5. Share the following research in order to do a good research in the use of teaching methods suitable for biology subjects, and methods are more varied and interesting.

\section{Bibliography:-}

1. Sugiyono 2011; Mixed Methods; Alfabeta; Bandung. Taryono;2000; Skilled Mastering and Applying Biology Commission of SMU 2A PT Tigaserangkai; PustakaMandiri Ngalimun; Learning Strategies and Models; 2015;AswajaPressindo; Banjarmasin.

2. Vienna Sanjaya; Planning and Design of Learning System; 2008; Bandung. Name of Mahasiawa / Email: JoaozitoBareto/baretojoaozito@gmail.com Name of Supervisor I / Email: Prof. Drs. JosuaBire, M.A, M.Ed, Phd / Name of Supervisor II / Email: Dr. GeradusUda., M.Pd 